\title{
GRAPEVINE ROOT DISTRIBUTION IN DRIP AND MICROSPRINKLER IRRIGATION
}

\author{
Luis Henrique Bassoi ${ }^{1 *}$; Jan W. Hopmans²; Lúcio André de Castro Jorge ${ }^{3}$; Cristina Miranda de \\ Alencar ${ }^{4}$; José Antonio Moura e Silva ${ }^{1}$ \\ ${ }^{I}$ Embrapa Semi-Árido - C.P. 23 - 56302-970 - Petrolina, PE - Brasil. \\ ${ }^{2}$ University of California - Department of Land, Air and Water Resources - Davis, CA - 95616 - USA. \\ ${ }^{3}$ Embrapa Instrumentação Agropecuária - C.P. 741 - 13560-970 - São Carlos, SP - Brasil. \\ ${ }^{4}$ UNESP/FCA - Depto. de Engenharia Rural - C.P. 237 - 18603-970 - Botucatu, SP - Brasil. \\ *Corresponding author <lhbassoi@cpatsa.embrapa.br>
}

\begin{abstract}
Grape (Vitis vinifera L.) yield and its quality are dependent of the status of the root system. Root distribution information is also valuable for soil and water management. An analysis of methods to evaluate the root distribution of grapevines for both, drip and microsprinkler irrigation in a Typic Acrustox is presented for the table grape cv. Italia grafted on the rootstock IAC-313, in northeastern Brazil. Measured root parameters using the monolith method were root dry weight $\left(\mathrm{D}_{\mathrm{w}}\right)$ and root length density $\left(\mathrm{L}_{\mathrm{v}}\right)$, while root area $\left(A_{p}\right)$ was estimated using the soil profile method in combination with digital image analysis. For both irrigation systems, roots were present to the $1 \mathrm{~m}$ soil depth and extended laterally to $1 \mathrm{~m}$ distance from the trunk, but grapevines irrigated by microsprinkler showed greater root presence as the distance from the trunk increased. Values of $A_{p}$ were reasonably well correlated to $\mathrm{D}_{w}$ and $\mathrm{L}_{\mathrm{v}}$. However, correlation values were higher when fractional root distribution was used. The soil profile method in combination with image analysis techniques, allows proper grapevine root distribution evaluation.

Key words: Vitis vinifera L., root system, digital image
\end{abstract}

\section{DISTRIBUIÇÃO RADICULAR DE VIDEIRAS IRRIGADAS POR GOTEJAMENTO E MICROASPERSÃO}

\begin{abstract}
RESUMO: A produção de uva (Vitis vinifera L.) em termos quantitativos e qualitativos depende do estado das raízes. Além disso, informações sobre a distribuição radicular são úteis para o manejo de solo e água. Por isso, uma análise de métodos para a avaliação da distribuição radicular de videiras cv. Itália / IAC 313 num Latossolo Vermelho Amarelo irrigadas por gotejamento e microaspersão foi realizada em Petrolina - PE e Juazeiro - BA, no Vale do São Francisco. Os parâmetros medidos pelo método do monolito foram a matéria seca $\left(D_{w}\right)$ e densidade de comprimento de raízes $\left(L_{v}\right)$, enquanto a área de raízes $\left(A_{p}\right)$ foi estimada pelo método do perfil de solo combinado com a análise de imagens digitais. Para ambos os sistemas de irrigação, as raízes estiveram presentes até $1 \mathrm{~m}$ de profundidade e estenderam-se lateralmente até $1 \mathrm{~m}$ de distância do tronco, mas as videiras irrigadas por microaspersão apresentaram uma maior presença de raízes com o aumento da distância do tronco. Os valores de $\mathrm{A}_{\mathrm{p}}$ apresentaram uma boa correlação com $\mathrm{D}_{\mathrm{w}}$ e $\mathrm{L}_{\mathrm{v}}$, mas essa correlação foi maior quando se utilizou a distribuição fracional de cada parâmetro. O método do perfil auxiliado pela análise de imagem digital permite a avaliação da distribuição radicular.

Palavras-chave: Vitis vinifera L., raízes, imagem digital
\end{abstract}

\section{INTRODUCTION}

The root system serves important physiological and biochemical functions, and it has been shown that both grape yield and quality are dependent on the health status of the roots (Morlat \& Jaquet, 1993). Many soil and management factors, such as temperature, mechanical resistance, aeration, texture, water and nutrient availability, $\mathrm{pH}$, frequency and depth of tillage, mulching and organic matter content, affect root distribution of grapevines (Kirchhof et al., 1991; Morlat \& Jaquet, 1993; Richards, 1983). In addition, root functionality is variable and depends on the grapevine cultivar or rootstock (Perry et al., 1983; Nagarajah, 1987; Morano \& Kliewer, 1994). Regarding water supply to roots, the type of irrigation system has been shown to affect root distribution (Morano \& Kliewer, 1994) as influenced by irrigation frequency, soil water availability, and spatial distribution of water and nutrients (Araujo et al., 1995; Clothier \& Green, 1997; van Zyl, 1988). Moreover, actual root water uptake not only depends on root distribution and its functioning, but also on soil water availability and salinity. In addition to water stress in periods of low water availability, root water uptake is also reduced when concentrations of 
soluble salts exceed plant-specific threshold values (Homaee, 1999). In irrigated soils, particularly in arid and semi-arid regions, plants are generally exposed to both, salinity and water stress. In these regions, soil and water management practices are based on maintaining a favorable soil water content and salinity status in the root zone, thereby minimizing periods of water stress while controlling leaching to minimize salinity stress. Furthermore, there is an increasing interest in the influence of soil water stress on grape and wine qualities (Bravdo \& Hepner, 1987; Freeman, 1990; Matthews \& Anderson, 1988; Myburgh, 1994; van Zyl \& van Huyssteen, 1984). These issues, in combination, justify studying the interrelationships between irrigation water management, root distribution grape, yield and quality.

Grapevine root growth initiates after bud burst and growth rates increase rapidly to a maximum at the blooming stage, after which the growth rate decreases. However, a new growth period starts after harvest (van Zyl, 1988). Depending on age, structural roots vary in diameter but are usually between $6-100 \mathrm{~mm}$. From the main framework, smaller permanent roots (diameter 2-6 $\mathrm{mm}$ ) arise and grow either horizontally or vertically. These roots extend and branch in a few main extension roots that are generally thin (diameter 1-2 $\mathrm{mm}$ ) and grow rapidly. These finer roots die within weeks after emergence but are replaced continuously (Richards, 1983).

Root distribution refers to the presence of roots within a fixed grid. Typically, root distribution studies include root biomass or root length as a function of soil depth, distance from the plant stem, and position between neighboring plants. Measurement of root distribution in agricultural communities often includes roots of more than one plant. Root architecture refers to the spatial configuration of the root system, specifically focusing on the geometric properties of root axes and laterals, mostly concerned with the entire root system characteristics (Lynch, 1995). Image analysis may provide all required information on root distribution and architecture, allowing for an explicit characterization of water and nutrient exploration, comparisons between plant cultivars and soil and water management practices.

Root analysis as a tool to study root behavior may benefit from using a combination of various measurement methods (Atkinson, 1980). Although root distribution analysis by the monolith method is difficult, laborious and time-consuming (Bohm, 1979), it provides detailed information on root length and diameter within a soil profile. Despite the fact that finer roots are more likely involved in plant water uptake, evidence has been presented that the larger suberized roots can also be effective in water and nutrient acquisition (Kozinka, 1991; van Zyl, 1988). However, because of uncertainties about the relationship of root diameter to their function, generally, the root length within a soil volume unit has been adopted (root length density, $\mathrm{L}_{\mathrm{v}}$ ) to characterize root presence (Klepper, 1992). In the trench or profile wall method (Bohm, 1979), digital image analysis can provide information for the required quantitative root analysis. From the digital pictures of roots exposed in a trench wall, root area $\left(\mathrm{A}_{\mathrm{p}}\right)$ and root length $\left(\mathrm{L}_{\mathrm{p}}\right)$ can be estimated using an image processing technique (Crestana et al., 1994). Moreover, root biomass can be determined from root area measurements, as suggested by Ruark \& Bockhein (1988) in aspen roots analysis in trench walls. Many other studies have shown the feasibility, accuracy and procedures of digital image analysis to estimate root area, root length and root diameter (Bauhus \& Messier, 1999; Commins et al., 1991; Dowdy et al., 1998; Kaspar \& Ewing, 1997; Kimura et al., 1999; Murphy \& Smucker, 1995; Tagliavini et al., 1993).

The objectives of this study were to analyze root distribution of grapevines, and to determine root distribution as affected by irrigation methods and soil types. Specifically, differences in root characteristics were measured for microsprinkler and drip irrigation systems for the IAC-313 rootstock in Petrolina, PE, Brazil. For this purpose, both the soil profile method with digital image analysis (Crestana et al., 1994; Bassoi et al., 1999) and the monolith method (Bohm, 1979) were used. In another commercial grape growing area located in Juazeiro, BA, Brazil, an evaluation of root distribution of the same rootstock in a different soil type was also conducted, using the trench method only. Both neighboring counties are sited along the São Francisco River and are important table grape production areas of the São Fancisco Valley of the semi-arid region of northeastern Brazil.

\section{MATERIAL AND METHODS}

\section{Petrolina County}

Two field trials were carried out in Petrolina, PE, Brazil $\left(09^{\circ} 09^{\prime} \mathrm{S}, 40^{\circ} 22^{\prime} \mathrm{W}\right.$, altitude $\left.365.5 \mathrm{~m}\right)$. The region has characteristics to grow grapevine with two harvests a year, because of the warm temperatures that prevail throughout the year (Araújo, 1994). The grapevines $\mathrm{cv}$. Italia grafted on the rootstock IAC-313 were planted in September 1991 in a 4 x 2 m grid (rows x plants) on a Typic Acrustox of average bulk density $1.6 \mathrm{Mg} \mathrm{m}^{-3}$. The soil is classified as medium-textured $\left(140 \mathrm{~g} \mathrm{~kg}^{-1}\right.$, $80 \mathrm{~g} \mathrm{~kg}^{-1}$ and $780 \mathrm{~g} \mathrm{~kg}^{-1}$ of clay, silt and sand, respectively), and the average soil water retention corresponds to $128.4 \mathrm{~g} \mathrm{~kg}^{-1}$ and $44.9 \mathrm{~g} \mathrm{~kg}^{-1}$ at $10 \mathrm{kPa}$ and $1500 \mathrm{kPa}$, respectively. The chemical characteristics of the soil profile (Table 1) were determined down to the $1 \mathrm{~m}$ depth as described by EMBRAPA (1997). Grapevines were irrigated either by microsprinkler (flow rate of $40 \mathrm{~L} \mathrm{~h}^{-1}$ with a wetting radius of $2 \mathrm{~m}$ ), spaced every $4 \mathrm{~m}$ along the plant row and centered between two plants, or by 
drip emitters (flow rate of $3.7 \mathrm{~L} \mathrm{~h}^{-1}$ ), spaced $1 \mathrm{~m}$ apart along a double drip line $(10 \mathrm{~cm}$ distance between plant row and drip lines on either side of the grapevines). Irrigation scheduling was based on pan-A evaporation data, using crop coefficients obtained in 1994 in the same area (Teixeira et al, 1999), and identical daily water application amounts were used for both irrigation systems. Root distribution was measured after blooming in two subsequent growing seasons, using the soil profile method combined with digital image analysis (Crestana et al., 1994; Bassoi et al., 1999) and the monolith method (Bohm, 1979).

\section{Soil profile method}

For crops on both irrigation systems, 1-m deep and $2-\mathrm{m}$ wide trenches were dug between plant rows to expose half of the root system of each of the two grapevine plants, in October 1995 and for other two in April 1996 ( 2 m long wall, one plant along each side of the trench). The distance between trench wall and center of plant row was $1 \mathrm{~m}$.
A thin layer of soil $(1-2 \mathrm{~cm})$ was carefully removed from the excavated vertical soil wall along the whole trench, and visible roots (generally with diameter larger than $1 \mathrm{~mm}$ ) were painted with white ink to enhance color contrast of the roots and the soil. A $1 \times$ $1 \mathrm{~m}$ wire-wood frame with a wire grid of $0.2 \times 0.2 \mathrm{~m}$ was pressed against the trench wall and video images were collected for each of the $0.04 \mathrm{~m}^{2}$ areas along the whole trench. The image collection procedure was repeated in several distances $(1.0,0.8,0.6,0.4$, and 0.2 $\mathrm{m})$ from plant row. Root images were digitized with a resolution of $640 \times 480$ pixels, saved as BMP files and processed by the Integrated System for Root and Soil Coverage Analysis (SIARCS ${ }^{\circledR}$ ) software (Crestana et al., 1994). From each image, root areas $\left(A_{p}, m^{2}\right)$ were determined. Average $A_{p}$ values $\left(\bar{A}_{p}\right)$ were computed from two subsequent trench walls, e.g., making up the front and back of each $0.2 \mathrm{~m}$ thick soil slab, corresponding to distances of $0.2-0.4,0.4-0.6,0.6-0.8$, and $0.8-1.0 \mathrm{~m}$ from the plant row.

Table 1 - Chemical characteristics of the soil of Petrolina and Juazeiro trials.

\begin{tabular}{|c|c|c|c|c|c|c|c|c|c|c|c|}
\hline depth & $\mathrm{pH}$ & E.C. & $\mathrm{P}$ & O.M. & $\mathrm{Ca}^{2+}$ & $\mathrm{Mg}^{2+}$ & $\mathrm{Na}^{+}$ & $\mathrm{K}^{+}$ & $\mathrm{H}+\mathrm{Al}$ & $\mathrm{Al}^{+3}$ & $\mathrm{~V}$ \\
\hline $\mathrm{m}$ & & $\mathrm{dS} \mathrm{m}^{-1}$ & $\mathrm{mg} \mathrm{dm}{ }^{-3}$ & $\mathrm{~g} \mathrm{dm}^{-3}$ & $-\cdots$ & & -- mr & $a^{-3}--$ & $\cdots$ & 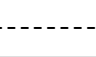 & $--\%$ \\
\hline \multicolumn{12}{|c|}{ Petrolina microsprinkler 1995} \\
\hline $0-0.2$ & 6.2 & 0.33 & 107 & 0.96 & 2.5 & 2.0 & 0.02 & 0.6 & 3.0 & 0.5 & 63 \\
\hline $0.2-0.4$ & 6.2 & 0.49 & 96 & 0.61 & 2.6 & 1.4 & 0.02 & 0.6 & 2.4 & 0.5 & 66 \\
\hline $0.4-0.6$ & 5.1 & 0.84 & 93 & 0.53 & 2.4 & 1.5 & 0.03 & 0.5 & 3.8 & 2.0 & 54 \\
\hline $0.6-0.8$ & 4.4 & 0.73 & - & - & 1.4 & 1.6 & 0.03 & 0.5 & 4.7 & 8.5 & 43 \\
\hline $0.8-1.0$ & 4.2 & 0.57 & - & - & 1.6 & 1.7 & 0.03 & 0.4 & 5.1 & 10.5 & 42 \\
\hline \multicolumn{12}{|c|}{ Petrolina drip 1995} \\
\hline $0-0.2$ & 6.5 & 1.21 & 117 & 0.73 & 2.3 & 1.7 & 0.03 & 0.6 & 1.8 & 0.5 & 72 \\
\hline $0.2-0.4$ & 6.0 & 0.87 & 123 & 0.55 & 2.9 & 1.0 & 0.03 & 0.6 & 1.6 & 0.5 & 74 \\
\hline $0.4-0.6$ & 5.4 & 1.18 & 94 & 0.47 & 2.6 & 2.1 & 0.05 & 0.6 & 2.6 & 1.0 & 67 \\
\hline $0.6-0.8$ & 4.6 & 1.19 & - & - & 3.4 & 1.0 & 0.05 & 0.6 & 2.4 & 2.5 & 68 \\
\hline $0.8-1.0$ & 4.4 & 1.49 & - & - & 2.7 & 2.1 & 0.05 & 0.5 & 2.9 & 3.5 & 65 \\
\hline \multicolumn{12}{|c|}{ Petrolina microsprinkler 1996} \\
\hline $0.0-0.2$ & 4.5 & 0.87 & 37 & 1.26 & 0.9 & 0.6 & 0.02 & 0.2 & 4.1 & 3.0 & 31 \\
\hline $0.2-0.4$ & 4.7 & 0.75 & 69 & 1.54 & 1.7 & 0.5 & 0.02 & 0.3 & 4.6 & 4.0 & 34 \\
\hline $0.4-0.6$ & 5.3 & 0.74 & 59 & 1.05 & 2.0 & 1.2 & 0.02 & 0.4 & 3.5 & 1.5 & 50 \\
\hline $0.6-0.8$ & 5.0 & 0.91 & 83 & 0.94 & 2.6 & 1.0 & 0.03 & 0.5 & 2.9 & 1.5 & 58 \\
\hline $0.8-1.0$ & 5.4 & 1.57 & 69 & 0.63 & 3.0 & 1.8 & 0.11 & 0.7 & 1.6 & 1.0 & 78 \\
\hline \multicolumn{12}{|c|}{ Petrolina drip 1996} \\
\hline $0.0-0.2$ & 5.0 & 0.63 & 78 & 1.39 & 2.0 & 0.9 & 0.05 & 0.3 & 3.3 & 1.5 & 50 \\
\hline $0.2-0.4$ & 4.9 & 0.56 & 96 & 1.09 & 1.7 & 0.5 & 0.02 & 0.3 & 3.9 & 2.0 & 39 \\
\hline $0.4-0.6$ & 4.5 & 0.69 & 127 & 0.88 & 1.8 & 1.2 & 0.03 & 0.3 & 4.9 & 4.0 & 41 \\
\hline $0.6-0.8$ & 5.2 & 0.90 & 79 & 0.91 & 2.6 & 1.3 & 0.05 & 0.4 & 0.5 & 1.0 & 89 \\
\hline $0.8-1.0$ & 5.6 & 1.30 & 32 & 1.06 & 3.4 & 1.2 & 0.09 & 0.6 & 1.5 & 0.5 & 78 \\
\hline \multicolumn{12}{|c|}{ Juazeiro furrow 1997} \\
\hline $0.0-0.2$ & 7.0 & 0.66 & 120 & 1.96 & 7.6 & 0.7 & 0.07 & 0.6 & 0.0 & 0.0 & 100 \\
\hline $0.2-0.4$ & 6.7 & 0.72 & 64 & 0.98 & 6.9 & 2.2 & 0.04 & 0.6 & 1.4 & 0.1 & 87 \\
\hline $0.4-0.6$ & 6.6 & 0.39 & 16 & 0.71 & 6.9 & 1.2 & 0.05 & 0.5 & 1.5 & 0.1 & 85 \\
\hline $0.6-0.8$ & 6.6 & 0.28 & - & - & 8.1 & 2.5 & 0.05 & 0.3 & 1.6 & 0.1 & 87 \\
\hline $0.8-1.0$ & 6.5 & 0.31 & - & - & 8.2 & 2.1 & 0.07 & 0.3 & 1.2 & 0.1 & 90 \\
\hline
\end{tabular}

E.C.: electric conductivity; O.M.: organic matter 


\section{Monolith method}

After image collection of each trench wall, monoliths of $0.008 \mathrm{~m}^{3}$, corresponding to the $0.2 \times 0.2 \mathrm{~m}$ imaged area and to the $0.2 \mathrm{~m}$ soil thickness, were sampled for two plants, in 1995 and 1996. As the trenches were excavated between two plant rows, sampling was performed on root systems on each side of the trenches. Monoliths were collected at distances of 1.0-0.8, 0.8-0.6, 0.6-0.4, and 0.4-0.2 $\mathrm{m}$ from plant rows. In the field, the roots of the monoliths were carefully separated from the soil using a $4 \mathrm{~mm}$ mesh sieve. Subsequently, fresh roots were washed in the laboratory, classified in four diameter (d) intervals: $\mathrm{d} \leq 2 \mathrm{~mm}$, $2<\mathrm{d} \leq 5 \mathrm{~mm}, 5<\mathrm{d} \leq 10 \mathrm{~mm}$, and $\mathrm{d}>10 \mathrm{~mm}$, and oven dried at $65^{\circ} \mathrm{C}$ before counting. For each diameter interval, dry weight $\left(\mathrm{D}_{\mathrm{w}}, \mathrm{g}\right)$ and root length $(\mathrm{L}, \mathrm{m})$ was estimated using the line intersection method (Tennant, 1975). Grid sizes of $0.01 \times 0.01 \mathrm{~m}$ and $0.02 \times 0.02 \mathrm{~m}$ were used for counting root line intersections for $\mathrm{d} \leq 10 \mathrm{~mm}$ and $\mathrm{d}>10$ $\mathrm{mm}$, respectively. Root length density $\left(\mathrm{L}_{\mathrm{v}}, \mathrm{m} \mathrm{m}^{-3}\right)$ was obtained from the estimated $\mathrm{L}$ divided by the monolith volume $\left(\mathrm{V}=0.008 \mathrm{~m}^{3}\right)$.

\section{Statistical analysis}

The root parameters $\left(D_{w}, \bar{A}_{p}\right.$ and $\left.L_{v}\right)$ for the two irrigations systems were analyzed in relation to four distance intervals from plants, and five soil depths using a repeated measure design. As measurements were repeated over the soil profile, the root count at one depth (soil layer $0.2 \mathrm{~m}$ thick) is not independent of the root count of the next depth, for a homogeneous soil. So counts over several depths were considered repeated spatial measurements (Morano \& Kliewer, 1994). For each irrigation system, two replications were sampled and analyzed for $\mathrm{D}_{\mathrm{w}}$, $\overline{\mathrm{A}}_{\mathrm{p}}$ and $\mathrm{L}_{\mathrm{v}}$ data of 1995 and 1996.

To better understand the relationships between root measurements, $\overline{\mathrm{A}}_{\mathrm{p}}$ - was calculated from the front and the back sides of a monolith - was correlated with $\mathrm{D}_{\mathrm{w}}$ and $\mathrm{L}_{\mathrm{v}}$, obtained from the inside of the same soil volume. Values of $\mathrm{D}_{\mathrm{w}}, \mathrm{L}_{\mathrm{v}}$, and $\overline{\mathrm{A}}_{\mathrm{p}}$ were added over each $0.2 \mathrm{~m}$ soil depth and along the trench wall, and fractional distributions of root parameters were also correlated. These comparisons were performed for all distance intervals and for both irrigation systems.

\section{Model application}

A simple model to predict the vertical root distribution was applied to root parameters measured by both, the trench wall and monolith methods, based on an asymptotic equation (Gale \& Grigal, 1987): $Y=1-\left(B^{D}\right)$, where $\mathrm{Y}$ is the cumulative fraction of a root density parameter (between 0 and 1) measured from soil surface to a depth $\mathrm{D}(\mathrm{m})$, and $\mathrm{B}$ is a fitting coefficient.

\section{Juazeiro County}

In a separated field experiment in 1997, the root distribution of the grapevine cv. Piratininga, grafted on the rootstock IAC-313, was measured using the soil profile method combined with digital image analysis, to demonstrate its application in a farmer's field. Grapevines were planted in 1990 using a $3.5 \times 2 \mathrm{~m}$ spacing, in a clayey soil (540 $\mathrm{g} \mathrm{kg}^{-1}, 90 \mathrm{~g} \mathrm{~kg}^{-1}, 370 \mathrm{~g} \mathrm{~kg}^{-1}$ of clay, silt and sand, respectively), and with a bulk density of 1.4 $\left.\mathrm{Mg} \mathrm{m}^{-3}\right)$. Average soil water retention at $10 \mathrm{kPa}$ and 1500 $\mathrm{kPa}$ were $19.6 \mathrm{~g} \mathrm{~kg}^{-1}$ and $10.3 \mathrm{~kg}^{-1}$, respectively. Chemical characteristics of this soil (Table 1) were also determined as described by EMBRAPA (1997). Vines were irrigated using furrows on each side of the vine row. Two trenches ( $1 \mathrm{~m}$ deep and $2 \mathrm{~m}$ long) were excavated to expose the rooting system of one vine trunk in the center of each trench. Field procedures for image collection were the same as described earlier. Root distribution was analyzed at several distances $(1.0,0.8,0.6,0.4$, and $0.2 \mathrm{~m})$ from the trunk. In addition the $A_{p}$, root length in the soil profile $\left(\mathrm{L}_{\mathrm{p}}, \mathrm{m}\right)$ was measured in this trial. Average values $\left(\overline{\mathrm{A}}_{\mathrm{p}}\right.$ and $\overline{\mathrm{L}}_{\mathrm{p}}$, respectively) were obtained from two subsequent trench walls as described in the Petrolina County experiment. In addition, root length density data were computed from the images, assuming that the volumetric root fraction (VRF, $\mathrm{m}^{3}$ of roots per $\mathrm{m}^{3}$ of soil) is equal to the areal root fraction (ARF, $\mathrm{m}^{2}$ of roots per $\mathrm{m}^{2}$ of soil), and that the total root volume within each $0.2 \mathrm{x}$ $0.2 \times 0.2 \mathrm{~m}^{3}$ bulk soil volume is equal to $\pi \hat{r}^{2} \succeq_{\mathrm{p}}$ (Bassoi et al., 1999):

$$
\begin{aligned}
& \mathrm{VRF}=\mathrm{ARF}=>\left(\pi \hat{r}^{2} \biguplus_{\mathrm{p}}\right) /(0.2 \times 0.2 \times 0.2)=\overline{\mathrm{A}}_{\mathrm{p}} /(0.2 \times 0.2) \\
& \overline{\mathrm{L}}_{\mathrm{p}}=\left(\overline{\mathrm{A}}_{\mathrm{p}} \times 0.2\right) /\left(\pi \hat{r}^{2}\right) \\
& \mathrm{L}_{\mathrm{v}, \mathrm{p}}=\mathrm{t}_{\mathrm{p}} /(0.2 \times 0.2 \times 0.2)=\mathrm{ARF} /\left(\pi \hat{r}^{2}\right)
\end{aligned}
$$

where $\mathrm{L}_{\mathrm{v}, \mathrm{p}}$ denotes the root length density as estimated from the soil profile method $\left(\mathrm{m} \mathrm{m}^{-3}\right)$, and $\hat{r}(\mathrm{~m})$ is the average root radius as estimated by the $\left(\mathrm{A}_{\mathrm{p}} / \mathrm{L}_{\mathrm{p}}\right)$ ratio of both images of the $0.008 \mathrm{~m}^{3}$ root volume (both trench faces).

\section{RESULTS AND DISCUSSION}

\section{Petrolina County}

A considerable variation on the total value (whole plant) of $\mathrm{D}_{\mathrm{w}}$ and $\mathrm{L}$ was observed between the two grapevines in both years, even on a same irrigation system. In 1995, total $\mathrm{D}_{\mathrm{w}}$ values were 1.23 and $0.34 \mathrm{~kg}$ for microsprinkler, and 1.03 and $0.71 \mathrm{~kg}$ for drip irrigated plants. Corresponding total $\mathrm{L}$ values were 473.5 and $252.5 \mathrm{~m}$ for microsprinkler, and 475.8 and $417.2 \mathrm{~m}$ for drip irrigated plants. In 1996, total $\mathrm{D}_{\mathrm{w}}$ from vines irrigated by microsprinkler were 1.36 and $0.46 \mathrm{~kg}$, while for those irrigated by drip values were 0.84 and $1.06 \mathrm{~kg}$. Respectively, total L values were 564.5 and $264.2 \mathrm{~m}$ for microsprinkler, and 396.8 and $506.0 \mathrm{~m}$ for drip irrigated plants. In both years, roots with $\mathrm{d} \leq 5 \mathrm{~mm}$ were approxi- 
mately $50 \%$ or more of total $\mathrm{D}_{\mathrm{w}}$, while roots with $\mathrm{d} \leq 2$ $\mathrm{mm}$ corresponded to at least $80 \%$ of total L. Other studies have shown that most of the roots were found within $\mathrm{d}<0.5 \mathrm{~mm}$ (van Zyl, 1988), $\mathrm{d}<1 \mathrm{~mm}$ (Morlat \& Jacquet, 1993), and $\mathrm{d}<2 \mathrm{~mm}$ (Morano \& Kliewer, 1994; Padjett-Johnson, 1999). The variation is possibly a consequence of the extension and direction of root growth, which is predominantly a random phenomenon influenced by gravity, soil resistance, temperature and availability of carbohydrate from the leaves, nutrient and water availability and gaseous exchange within the soil (Rowe, 1993). Also, strong spatial heterogeneity of root distribution, volumetric root expansion, frequent asymmetry on either side of plant rows, and a great variability in root diameter are the main constraints for root studies in vineyards (Morlat \& Jacquet, 1993). The average $\mathrm{L}$ for drip $(448.93 \pm 50.64 \mathrm{~m})$ was higher than that of microsprinkler-irrigated plants $(388.70 \pm 155.05$ $\mathrm{m}$ ), which is similar in relation to other results (Stevens \& Douglas, 1994). Variability of total root length of vines did not make possible any conclusion on the effect of soil texture on root development (Nagarajah, 1987).

There were no differences between root parameters under both irrigation systems while all comparisons were significant between soil profiles, soil depths and their interactions. The closer to the trunk, the greater is the amount of roots in the horizontal direction, as well as in the vertical direction. $\mathrm{D}_{\mathrm{w}}$ was not significant for irrigation and soil profile interaction in 1995, and for irrigation and soil depth interaction in 1996, while $\mathrm{L}_{v}$ and $\overline{\mathrm{A}}_{\mathrm{p}}$ presented significant differences for both years (Table 2).

In the horizontal direction (irrigation and soil profile interaction), the t-test was significant for root parameters in some sites. For the most distant samples from trunk $(0.8-1 \mathrm{~m}), \mathrm{D}_{\mathrm{w}}$ and $\overline{\mathrm{A}}_{\mathrm{p}}$ of the microsprinkler-irrigated grapevines presented higher values (except for $\overline{\mathrm{A}}_{\mathrm{p}}$ in 1995), while near the trunk (0.2-0.4 and 0.4-0.6 m), drip-irrigated plants presented significant higher root parameters. In the vertical direction (irrigation and soil depth interaction), soil layers until $0.6 \mathrm{~m}$ presented some root parameters with higher values for plants irrigated by drip, and some higher values for plants irrigated by microsprinkler for the deeper soil layer (Table 3).

In the significant interactions between irrigation and soil profile and soil depth, the t-test between the same soil depth interval in the same soil profile indicated that few portions of the root system had differences between both irrigation systems. But for those with differences, this occurred at the greatest distance from the trunk (0.8-1 $\mathrm{m}$ soil profile) and in the deepest soil layer (0.8-1 m depth); microsprinkler-irrigated plants presented greater root presence than those irrigated by drippers, in almost all sampling sites. A clear tendency of greater values of drip irrigated plants appeared in the upper $0.6 \mathrm{~m}$ soil depth and in the soil profiles between 0.2 and $0.6 \mathrm{~m} . \mathrm{L}_{v}$ and $\overline{\mathrm{A}}_{\mathrm{p}}$ values of 1996 trial are presented over the entire trench walls in vertical and horizontal directions in Figures 1 to 4. Closer to the trunk, values increased as well as the ones under microsprinkler presented higher values than those under drip irrigation in $0.8-1$ and $0.6-0.8 \mathrm{~m}$ soil profiles, while the opposite occurred for 0.4-0.6 and 0.2-0.4 m soil profiles. Higher values of $L_{v}$ and $\bar{A}_{p}$ were found near the soil surface due to manure application, a common practice of the grapevine production system in the São Francisco Valley. Generally, table grape growers have been applying $0.02-0.04 \mathrm{~m}^{3}$ of manure per vine in every growing season.

As grapevine root distribution in the soil profile is dependent of edaphic conditions (Nagarajah, 1987; Morlat \& Jacquet, 1993). Soil depth of highest root presence varied around $0.4 \mathrm{~m}$ (Nappi et al., 1985), $0.5 \mathrm{~m}$ (Padgett-Johnson, 1999), $0.8 \mathrm{~m}$ (Stevens \& Douglas, 1994), $1.0 \mathrm{~m}$ (Araújo et al., 1995), and $2.4 \mathrm{~m}$ (Williams $\&$ Smith, 1991). Some of the influence factors are the irrigation system, age of the plant, rootstock, spacing grid, and physic-chemical soil conditions. In this study, the upper $0.4 \mathrm{~m}$ soil profile presented the highest amount of root in both soils. Supposedly application of mamure has provided better root proliferation conditions in this soil

Table 2 - Analysis of variance $(P<0.05)$ with a repeated measurement design of root dry weight $\left(\mathrm{D}_{\mathrm{w}}, \mathrm{kg}\right)$, root length density $\left(\mathrm{L}_{\mathrm{v}}, \mathrm{m} \mathrm{m}^{-3}\right)$, and root area $\left(\overline{\mathrm{A}}_{\mathrm{p}}, \mathrm{m}^{2}\right)$ of the grapevine $\mathrm{cv}$. Italia grafted on rootstock IAC-313, for different irrigation systems, soil profiles and depths in Petrolina.

\begin{tabular}{lccccccc}
\hline root parameter and year & $\begin{array}{c}\text { irrigation } \\
\text { system }\end{array}$ & soil profile & soil depth & $\begin{array}{c}\text { irrigation and } \\
\text { soil profile }\end{array}$ & $\begin{array}{c}\text { irrigation and } \\
\text { soil depth }\end{array}$ & $\begin{array}{c}\text { soil profile } \\
\text { and depth }\end{array}$ & $\begin{array}{c}\text { irrigation soil } \\
\text { rofile and depth }\end{array}$ \\
\hline $\mathrm{D}_{\mathrm{w}} 1995$ & $\mathrm{~ns}$ & $10^{-6}$ & $10^{-6}$ & $\mathrm{~ns}$ & 0.002589 & $10^{-6}$ & 0.005380 \\
$\mathrm{D}_{\mathrm{w}} 1996$ & $\mathrm{~ns}$ & $10^{-6}$ & $10^{-6}$ & 0.024387 & $\mathrm{~ns}$ & $10^{-6}$ & 0.017656 \\
$\mathrm{~L}_{\mathrm{v}} 1995$ & $\mathrm{~ns}$ & $10^{-6}$ & $10^{-6}$ & 0.005955 & $10^{-6}$ & $10^{-6}$ & $10^{-6}$ \\
$\mathrm{~L}_{\mathrm{v}} 1996$ & $\mathrm{~ns}$ & $10^{-6}$ & $10^{-6}$ & 0.005114 & 0.000791 & $10^{-6}$ & $10^{-6}$ \\
$\overline{\mathrm{A}}_{\mathrm{p}} 1995$ & $\mathrm{~ns}$ & $10^{-6}$ & $10^{-6}$ & 0.039798 & $2.10^{-6}$ & $10^{-6}$ & 0.002896 \\
$\overline{\mathrm{A}}_{\mathrm{p}} 1996$ & $\mathrm{~ns}$ & $10^{-6}$ & $10^{-6}$ & 0.005879 & 0.019473 & $10^{-6}$ & $10^{-6}$ \\
$\mathrm{~ns}_{\mathrm{ns}}$ not significant & & & & & & &
\end{tabular}


Table 3 - Comparison performed by the t-test $(P<0.05)$ between drip and microsprinkler irrigation systems of root dry weight $\left(\mathrm{D}_{\mathrm{w}}, \mathrm{kg}\right)$, root length density $\left(\mathrm{L}_{\mathrm{v}}, \mathrm{m} \mathrm{m}^{-3}\right)$, root area $\left(\overline{\mathrm{A}}_{\mathrm{p}}, 10^{-4} \mathrm{~m}^{2}\right)$ of the grapevine rootstock IAC-313 from significant interactions between irrigation versus soil profile and irrigation versus soil depth, for Petrolina.

\begin{tabular}{|c|c|c|c|c|c|c|c|c|c|c|c|}
\hline \multirow{3}{*}{\multicolumn{2}{|c|}{$\begin{array}{l}\text { root parameter } \\
\text { and year }\end{array}$}} & \multicolumn{10}{|c|}{ soil profile - m } \\
\hline & & \multicolumn{3}{|c|}{$0.2-0.4$} & \multicolumn{2}{|c|}{$0.4-0.6$} & \multicolumn{3}{|c|}{$0.6-0.8$} & \multicolumn{2}{|c|}{$0.8-1$} \\
\hline & & \multicolumn{2}{|c|}{ micro } & drip & micro & drip & \multicolumn{2}{|c|}{ micro } & drip & micro & drip \\
\hline$D_{w} 1996$ & & \multicolumn{2}{|c|}{$7.28 \mathrm{~b}$} & $10.36 \mathrm{a}$ & $4.16 \mathrm{a}$ & $4.51 \mathrm{a}$ & \multicolumn{2}{|c|}{$3.03 \mathrm{a}$} & $2.35 \mathrm{a}$ & $3.34 \mathrm{a}$ & $1.93 \mathrm{~b}$ \\
\hline$L_{v} 1995$ & & \multicolumn{2}{|c|}{319.7 a } & 337.9 a & $244.0 \mathrm{~b}$ & $389.2 \mathrm{a}$ & \multicolumn{2}{|c|}{$192.6 \mathrm{a}$} & $226.8 \mathrm{a}$ & $151.2 \mathrm{a}$ & $160.4 \mathrm{a}$ \\
\hline$L_{v} 1996$ & & \multicolumn{2}{|c|}{408.9 a } & $353.4 \mathrm{a}$ & $246.0 \mathrm{~b}$ & $349.4 \mathrm{a}$ & \multicolumn{2}{|c|}{$201.4 \mathrm{a}$} & $194.5 \mathrm{a}$ & $217.4 \mathrm{a}$ & $171.6 \mathrm{a}$ \\
\hline$\overline{\mathrm{A}}_{\mathrm{p}} 1995$ & & \multicolumn{2}{|c|}{$2.68 \mathrm{~b}$} & $3.39 \mathrm{a}$ & $3.94 \mathrm{~b}$ & $5.37 \mathrm{a}$ & \multicolumn{2}{|c|}{$5.98 \mathrm{~b}$} & $9.76 \mathrm{a}$ & $9.70 \mathrm{~b}$ & $12.88 \mathrm{a}$ \\
\hline \multirow[t]{4}{*}{$\overline{\mathrm{A}}_{\mathrm{p}} 1996$} & & \multicolumn{2}{|c|}{$11.80 \mathrm{~b}$} & $14.25 \mathrm{a}$ & $8.74 \mathrm{~b}$ & 11.26 & & $34 \mathrm{a}$ & $6.30 \mathrm{a}$ & $4.87 \mathrm{a}$ & $3.85 \mathrm{~b}$ \\
\hline & & & & & & soil de & pth - m & & & & \\
\hline & & & & 0.2 & 0.4 & 0.4 & 0.6 & 0.6 & $5-0.8$ & & $8-1$ \\
\hline & & cro & drip & micro & drip & micro & drip & micro & drip & micro & drip \\
\hline $\mathrm{D}_{\mathrm{w}} 1995$ & & $45 \mathrm{a}$ & $8.69 \mathrm{a}$ & $3.69 \mathrm{~b}$ & $6.53 \mathrm{a}$ & $3.96 \mathrm{a}$ & $2.16 \mathrm{a}$ & $2.65 \mathrm{a}$ & $2.17 \mathrm{a}$ & $2.83 \mathrm{a}$ & $2.10 \mathrm{a}$ \\
\hline $\mathrm{L}_{\mathrm{v}} 1995$ & 410 & $6 \mathrm{~b}$ & $566.0 \mathrm{a}$ & $211.9 \mathrm{~b}$ & $313.8 \mathrm{a}$ & $141.6 \mathrm{a}$ & $169.3 \mathrm{a}$ & $156.7 \mathrm{a}$ & $178.3 \mathrm{a}$ & $213.7 \mathrm{a}$ & $167.8 \mathrm{a}$ \\
\hline$L_{v} 1996$ & 563 & 6 a & $524.9 \mathrm{a}$ & $243.8 \mathrm{~b}$ & $384.2 \mathrm{a}$ & $118.2 \mathrm{~b}$ & $172.4 \mathrm{a}$ & $142.9 \mathrm{a}$ & $176.1 \mathrm{a}$ & $204.2 \mathrm{a}$ & $147.8 \mathrm{~b}$ \\
\hline$\overline{\mathrm{A}}_{\mathrm{p}} 1995$ & 10 & $58 \mathrm{~b}$ & $18.34 \mathrm{a}$ & $7.69 \mathrm{a}$ & $8.98 \mathrm{a}$ & $2.07 \mathrm{~b}$ & $3.75 \mathrm{a}$ & $3.76 \mathrm{a}$ & $4.55 \mathrm{a}$ & $3.78 \mathrm{a}$ & $3.62 \mathrm{a}$ \\
\hline$\overline{\mathrm{A}}_{\mathrm{p}} 1996$ & 18 & $34 \mathrm{a}$ & $18.24 \mathrm{a}$ & $9.45 \mathrm{~b}$ & $13.89 \mathrm{a}$ & $3.71 \mathrm{~b}$ & $5.76 \mathrm{a}$ & $4.47 \mathrm{a}$ & $4.37 \mathrm{a}$ & $3.98 \mathrm{a}$ & $2.31 \mathrm{~b}$ \\
\hline
\end{tabular}

a

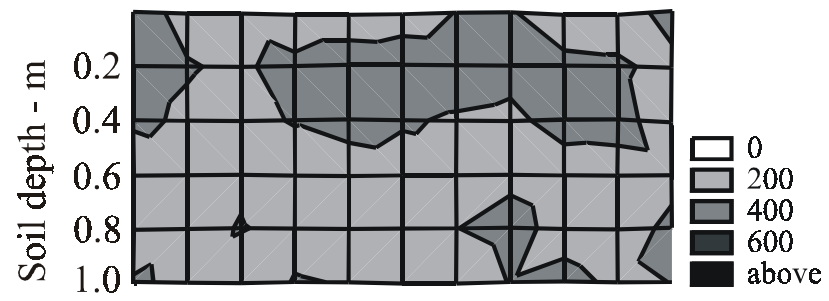

b

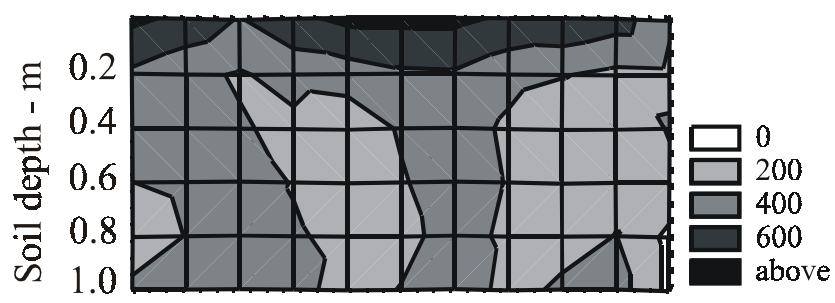

c

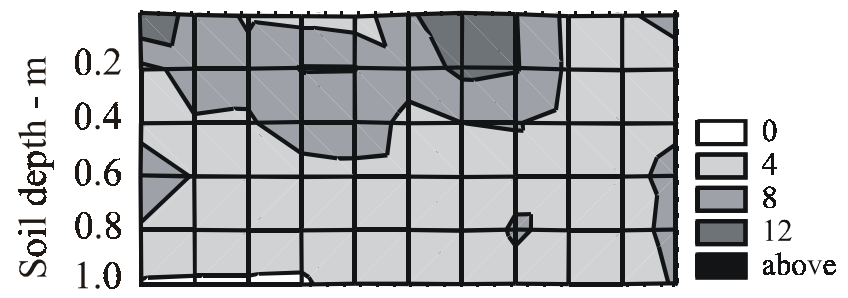

$\mathrm{d}$

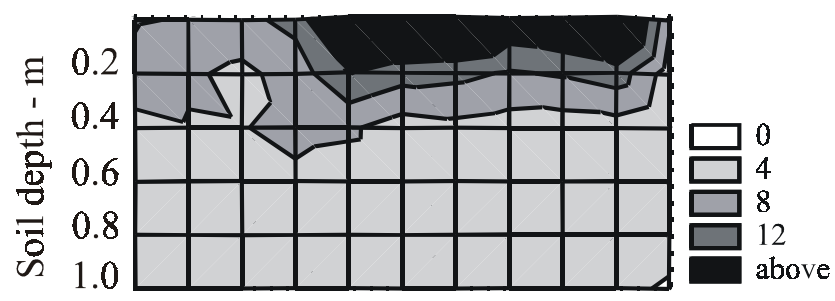

Figure $1-\mathrm{L}_{\mathrm{v}}$ - root length density $-\left(\mathrm{a}, \mathrm{b}-\mathrm{m} \mathrm{m}^{-3}\right)$ and $\overline{\mathrm{A}}_{\mathrm{p}}$ - root area $\left(\mathrm{c}, \mathrm{d}-10^{-4} \mathrm{~m}^{2}\right)$ distributions in the $0.8-1 \mathrm{~m}$ soil profile under drip $(\mathrm{a}, \mathrm{c})$ and microsprinkler $(\mathrm{b}, \mathrm{d})$ irrigation systems in Petrolina.

layer. Higher grapevine root presence in a sandy soil horizon was observed and related to higher organic matter content (Morlat \& Jacquet, 1993). The main factors for shallow rooting in tropical soils are low $\mathrm{pH}$, high exchangeable aluminum, compaction, inadequate aeration, and low retention and movement of water (Reichardt, 1981). In this study, soil $\mathrm{pH}$ ranged from 4.4 (deeper to upper layers) to 6.0 (upper layers), and organic matter content in deeper layers was low. Also, this soil presented over the $1 \mathrm{~m}$ depth low level of sodium, medium levels of calcium and magnesium, high contents of potassium and phosphorus, and medium base saturation (Table 1).
Stevens \& Douglas (1994) found that in the horizontal direction, roots of drip-irrigated plants were concentrated under the vine row, and $50 \%$ of the root length was within the $45 \mathrm{~cm}$ distance from the plant row in comparison with $35 \%$ of the plants irrigated by microsprinkler. A decrease in the grapevine root length from $0.3 \mathrm{~m}$ to $0.9 \mathrm{~m}$ distance from the trunk was also observed by Nagarajah (1987). In this study area, a greater amount of roots was within the $0.6 \mathrm{~m}$ distance from the plant row.

Water application by drippers close to the trunk provides smaller wetted soil volume mainly in the closer 
a

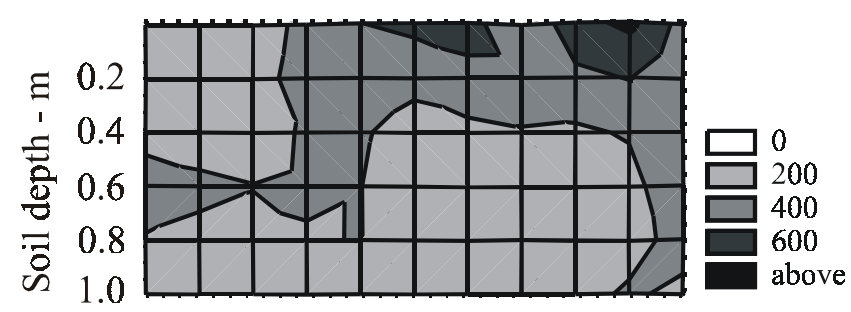

c

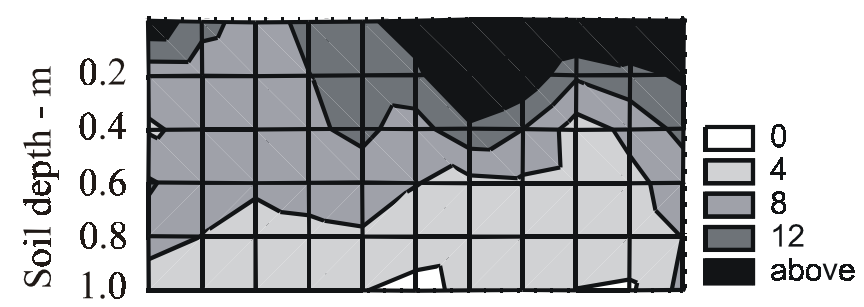

b

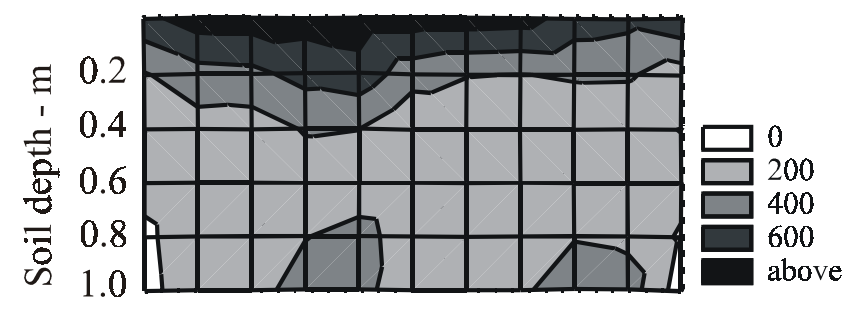

d

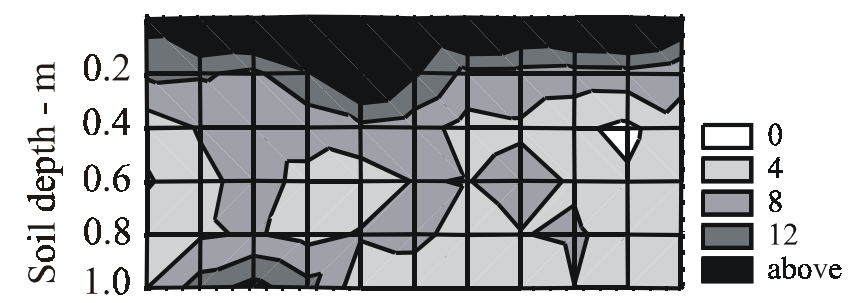

Figure $2-\mathrm{L}_{\mathrm{v}}$ - root length density $\left(\mathrm{a}, \mathrm{b}-\mathrm{m} \mathrm{m}^{-3}\right)$ and $\overline{\mathrm{A}}_{\mathrm{p}}$ - root area $\left(\mathrm{c}, \mathrm{d}-10^{-4} \mathrm{~m}^{2}\right)$ distributions in the 0.6-0.8 $\mathrm{m}$ soil profile under drip $(\mathrm{a}, \mathrm{c})$ and microsprinkler $(\mathrm{b}, \mathrm{d})$ irrigation systems in Petrolina.

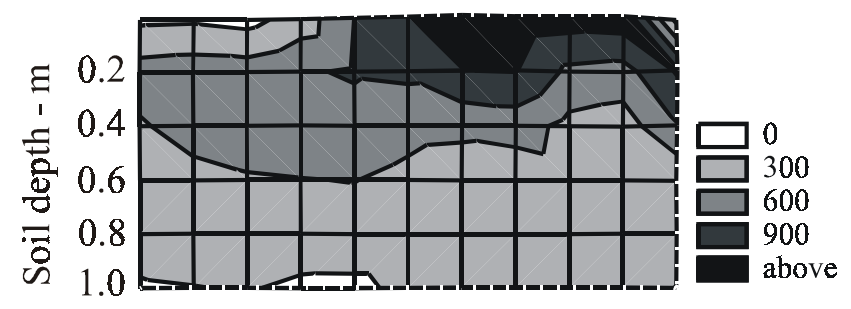

C

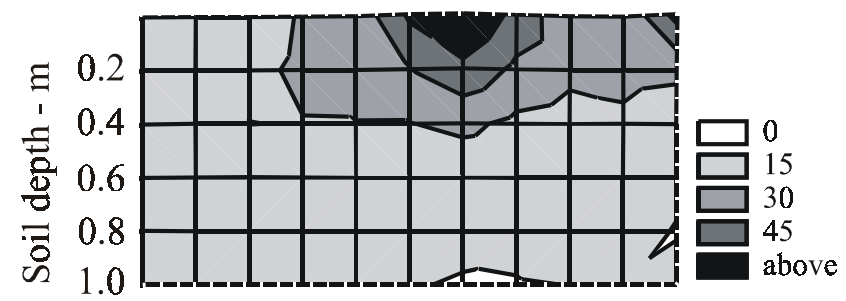

b

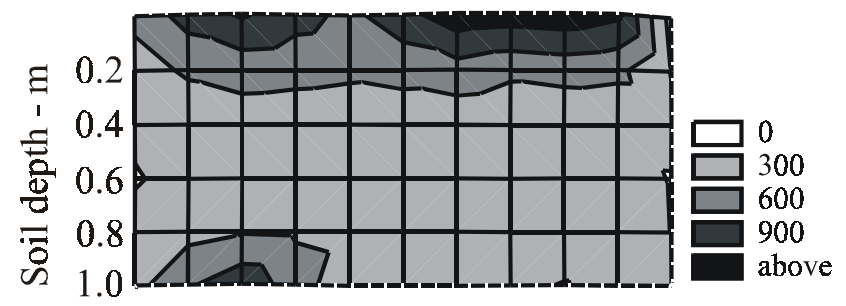

d

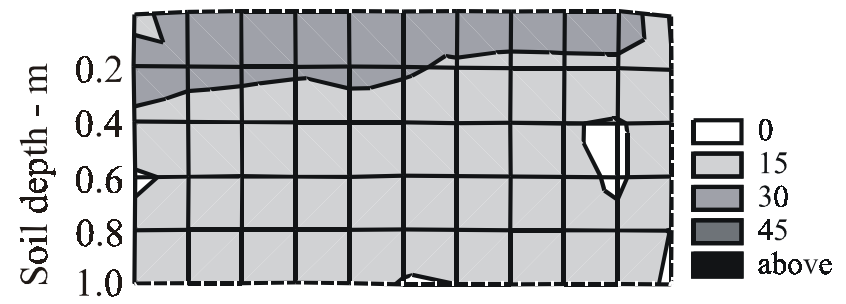

Figure $3-\mathrm{L}_{v}$ - root length density $\left(\mathrm{a}, \mathrm{b}-\mathrm{m} \mathrm{m}^{-3}\right)$ and $\overline{\mathrm{A}}_{\mathrm{p}}$ - root area $\left(\mathrm{c}, \mathrm{d}-10^{-4} \mathrm{~m}^{2}\right)$ distributions in the $0.4-0.6 \mathrm{~m}$ soil profile under drip $(\mathrm{a}, \mathrm{c})$ and microsprinkler $(b, d)$ irrigation systems in Petrolina.

soil portions at vertical and horizontal directions to trunk. Therefore, in some portions of the soil near the trunk, $\mathrm{L}_{\mathrm{v}}$ and $\overline{\mathrm{A}}_{\mathrm{p}}$ were higher for drip than for the correspondent positions in plants irrigated by microsprinklers. But root growing was spread over the longitudinal direction in relation to the plant rows, because of the $2 \mathrm{~m}$ wetting radius of the microsprinklers, emitter disposals on each 1 $\mathrm{m}$ along the drip line, and the manure application, close and along plant rows. Besides of the differences on methods used for root sampling and measurement, $\mathrm{L}_{\mathrm{v}}$ values are in accordance with other authors (Nagarajah, 1987; van Zyl, 1988).

Normal precipitation (1963-1996) at Petrolina, measured at the climatic station located within the experimental area, was $573 \mathrm{~mm}$ per year, and $512 \mathrm{~mm}$ oc-

Scientia Agricola, v.60, n.2, p.377-387, Abr./Jun. 2003 cur between November and April (rainy season). As grapevine is cultivated over the entire year in this tropical fruit growing area, with two harvests per year (Araujo, 1994), the root growth during the rainy season may contribute also to minimize differences in root development under microsprinkler and drip irrigation systems.

Correlations obtained between $\mathrm{D}_{\mathrm{w}}, \mathrm{L}_{\mathrm{v}}$ and $\overline{\mathrm{A}}_{\mathrm{p}}$ for 1996 data were slightly better than those for 1995 , but in both years the $r^{2}$-values were not sufficiently high, even those between parameters measured inside the monolith. This occurred because the trench wall exposes part of the root system present inside the soil volume, and because roots with same $\mathrm{D}_{\mathrm{w}}$ may have different L values or vice-versa because of different root 
diameter. Correlation performed between the averaged fractional distribution of the root parameters for each 0.2 $\mathrm{m}$ soil layer along the trench wall, considering each plant and each soil profile, were high. The integration of the root parameter values provided this better relationship (Table 4). It means a good correspondence and, therefore, a support to the feasibility of the digital image analysis for this purpose.

The model to predict vertical root distribution was tested with $\mathrm{D}_{w}, \mathrm{~L}_{\mathrm{v}}$, and $\overline{\mathrm{A}}_{\mathrm{p}}$ measured in 1996

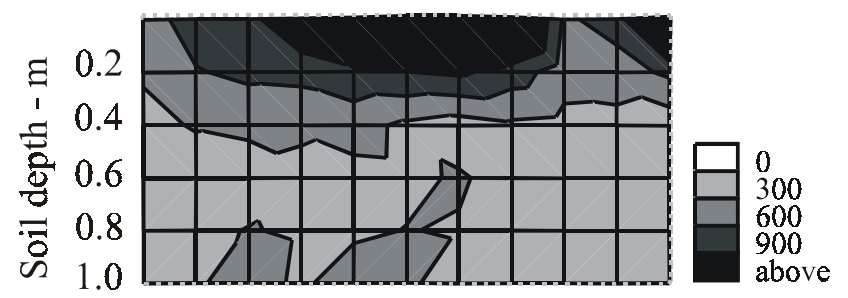

C

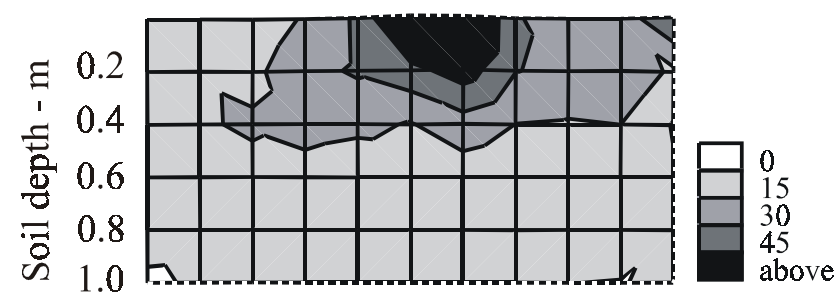

in two vines irrigated by microsprinkler for all soil profiles together (Figure 5). The variability of the values for a same soil depth is attributed to the variation of root presence in the different distances from the trunk, as already discussed. The equations presented high $\mathrm{r}^{2}$ values, and the $\mathrm{D}_{\mathrm{w}}, \mathrm{L}_{\mathrm{v}}$, and $\overline{\mathrm{A}}_{\mathrm{p}}$ variances were explained by $91.3,89.5$, and $95.2 \%$, respectively. Therefore, the vertical root distribution analysis can be accomplished using the parameters measured by both methods with this simple model, with acceptable accuracy.

b

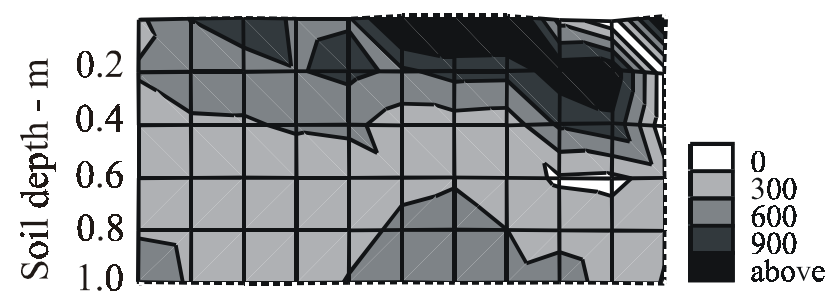

Figure $4-\mathrm{L}_{\mathrm{v}}$ - root length density $\left(\mathrm{a}, \mathrm{b}-\mathrm{m} \mathrm{m}^{-3}\right)$ and $\overline{\mathrm{A}}_{\mathrm{p}}$ - root area $\left(\mathrm{c}, \mathrm{d}-10^{-4} \mathrm{~m}^{2}\right)$ distributions in the $0.2-0.4 \mathrm{~m}$ soil profile under drip $(\mathrm{a}, \mathrm{c})$ and microsprinkler $(b, d)$ irrigation systems in Petrolina.

Table 4 - Linear equations $(y=a+b x)$, correlation coefficients for root dry weight $\left(\mathrm{D}_{\mathrm{w}}, \mathrm{kg}\right)$, root length density $\left(\mathrm{L}_{\mathrm{v}}\right.$, $\left.\mathrm{m} \mathrm{m}^{-3}\right)$, root area $\left(\overline{\mathrm{A}}_{\mathrm{p}}, \mathrm{m}^{2}\right)$, and root length $\left(\overline{\mathrm{L}}_{\mathrm{p}}, \mathrm{m}\right)$ of the grapevine rootstock IAC-313, and their fractional distribution comparisons in Petrolina (1995 and 1996) and Juazeiro (1997).

\begin{tabular}{|c|c|c|c|c|c|c|c|c|}
\hline \multirow[t]{2}{*}{ year } & coordinates & \multirow{2}{*}{$\begin{array}{c}\text { irrigation } \\
\text { system }\end{array}$} & \multicolumn{3}{|c|}{ parameter } & \multicolumn{3}{|c|}{ fractional distribution } \\
\hline & $\mathrm{x} \quad \mathrm{y}$ & & a & $\mathrm{b}$ & $r^{2}$ & $\mathrm{a}$ & $\mathrm{b}$ & $\mathrm{r}^{2}$ \\
\hline \multirow[t]{6}{*}{1995} & $\mathrm{D}_{\mathrm{w}} \times \mathrm{L}_{\mathrm{v}}$ & micro & 164.898 & 15.845 & 0.562 & 3.294 & 0.835 & 0.855 \\
\hline & & drip & 183.965 & 21.966 & 0.614 & 3.275 & 0.836 & 0.916 \\
\hline & $D_{w} \times \bar{A}_{p}$ & micro & $3.503 \mathrm{E}-4$ & $3.317 \mathrm{E}-5$ & 0.417 & 5.045 & 0.748 & 0.698 \\
\hline & & drip & $2.257 \mathrm{E}-4$ & $4.691 \mathrm{E}-5$ & 0.646 & 2.777 & 0.861 & 0.869 \\
\hline & $\mathrm{L}_{\mathrm{v}} \times \overline{\mathrm{A}}_{\mathrm{p}}$ & micro & $9.624 \mathrm{E}-5$ & $1.692 \mathrm{E}-6$ & 0.599 & 3.683 & 0.816 & 0.744 \\
\hline & & drip & $1.084 \mathrm{E}-4$ & $1.148 \mathrm{E}-6$ & 0.566 & 1.053 & 0.947 & 0.873 \\
\hline \multirow[t]{6}{*}{1996} & $\mathrm{D}_{\mathrm{w}} \times \mathrm{L}_{\mathrm{v}}$ & micro & 173.815 & 19.365 & 0.592 & 4.188 & 0.791 & 0.869 \\
\hline & & drip & 170.316 & 23.150 & 0.724 & 5.316 & 0.734 & 0.866 \\
\hline & $\mathrm{D}_{\mathrm{w}} \times \overline{\mathrm{A}}_{\mathrm{p}}$ & micro & $5.256 \mathrm{E}-4$ & $6.426 \mathrm{E}-5$ & 0.602 & 3.423 & 0.829 & 0.913 \\
\hline & & drip & $5.350 \mathrm{E}-4$ & $7.447 \mathrm{E}-5$ & 0.663 & 6.362 & 0.682 & 0.741 \\
\hline & $\operatorname{Lv} \times \bar{A}_{p}$ & micro & $2.233 \mathrm{E}-4$ & $2.240 \mathrm{E}-6$ & 0.687 & 1.110 & 0.944 & 0.946 \\
\hline & & drip & $1.180 \mathrm{E}-4$ & $2.751 \mathrm{E}-6$ & 0.783 & 0.628 & 0.969 & 0.893 \\
\hline \multirow[t]{3}{*}{1997} & $\overline{\mathrm{A}}_{\mathrm{p}} \times \overline{\mathrm{L}}_{\mathrm{p}}$ & furrow & 0.897 & 2292.72 & 0.858 & 4.350 & 0.783 & 0.968 \\
\hline & $\overline{\mathrm{A}}_{\mathrm{p}} \times \mathrm{L}_{\mathrm{v}, \mathrm{p}}$ & furrow & 39.749 & 47193.44 & 0.535 & 9.407 & 0.530 & 0.745 \\
\hline & $\overline{\mathrm{L}}_{\mathrm{p}} \times \mathrm{L}_{\mathrm{v}, \mathrm{p}}$ & furrow & 24.778 & 19.316 & 0.585 & 6.438 & 0.678 & 0.771 \\
\hline
\end{tabular}




\section{Juazeiro County}

Root distribution of the grapevine cv. Piratininga grafted on rootstock IAC-313 was evaluated by digital image analysis to obtain $\overline{\mathrm{A}}_{\mathrm{p}}, \overline{\mathrm{L}}_{\mathrm{p}}$, and $\mathrm{L}_{\mathrm{v}, \mathrm{p}}$, and an example of these results is presented for $\overline{\mathrm{A}}_{\mathrm{p}}$ in Figure 6 for comparison with results from the experimental area (Petrolina County). Roots reached the $1 \mathrm{~m}$ depth and the $1 \mathrm{~m}$ distance from the trunk and the amount increased in relation to the decrease of the distance from the plant row. This soil presented a higher $\mathrm{pH}$ and nutrient content than that of Petrolina (Table 1). The lack of roots near soil surface, specially in 0.4-0.6, 0.6-0.8, and 0.8-1 $\mathrm{m}$ distances, can be attributed to no manure application in this area. A much less fine root proliferation was observed in the field, particularly in the $0-0.4 \mathrm{~m}$ depth, as compared to the Petrolina County trial.
As observed for the experimental area, higher correlation coefficients were obtained with the fractional distribution correlation than with the parameter comparisons (Table 4). $\mathrm{L}_{\mathrm{v}}$ calculated by monolith data in the experimental area ranged from 10 to $2730 \mathrm{~m} \mathrm{~m}^{-3}$, while $\mathrm{L}_{\mathrm{v}, \mathrm{p}}$ (using trench wall data) of the Juazeiro County trial varied from 1 to $930 \mathrm{~m} \mathrm{~m}^{-3}$. The differences in magnitude between both root parameters are a consequence of the whole and partial exposure of the roots for measurement (respectively, $\mathrm{L}$ in the monolith method, and $\mathrm{A}_{\mathrm{p}}$ and $\mathrm{L}_{\mathrm{p}}$ in the soil profile method). In an indirect way, we found that fractional $\mathrm{L}_{\mathrm{p}}$ and $\mathrm{L}_{\mathrm{v}, \mathrm{p}}$ may be used to evaluate root distribution, given their correlation with $\overline{\mathrm{A}}_{\mathrm{p}}$.

The range of root diameter over the trench wall and estimated by $\mathrm{A}_{\mathrm{p}} / \mathrm{L}_{\mathrm{p}}$ ratio was $2.1-3.4,2.1-3.3,2.2$ - 3.7, $1.9-2.7,0.9-2.9 \mathrm{~mm}$, for soil profiles at $0.2,0.4$,
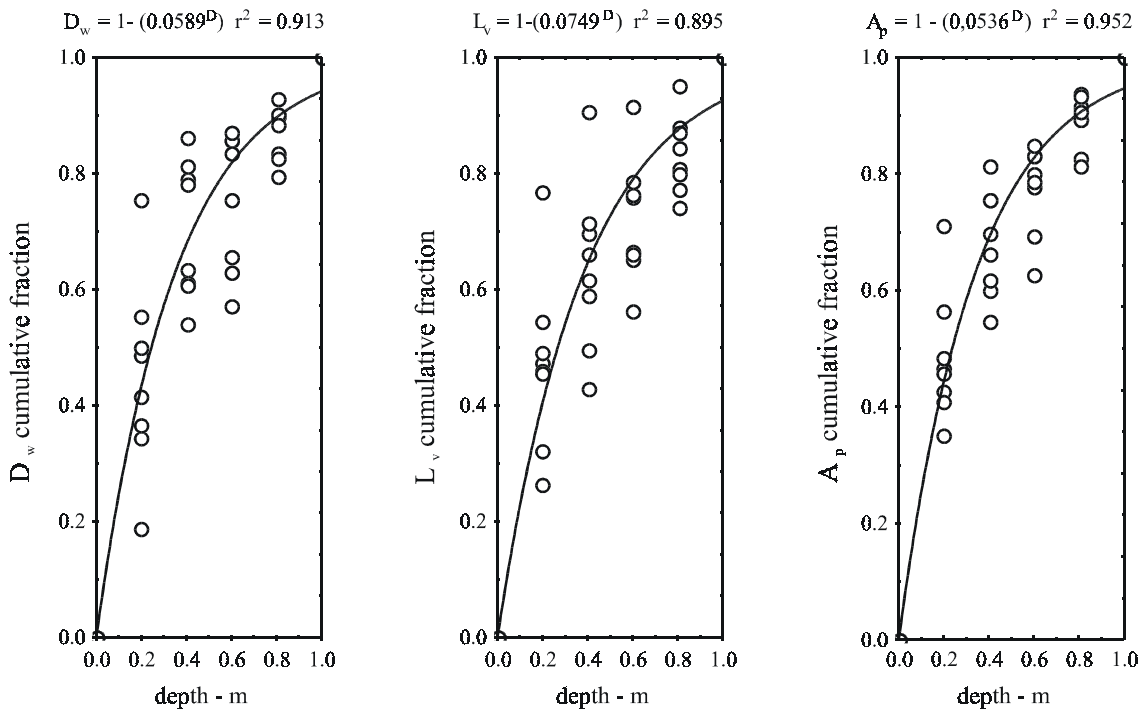

Figure 5 - Vertical root distribution based on the model $\mathrm{Y}=1-\left(\mathrm{B}^{\mathrm{D}}\right)$ of $\mathrm{D}_{\mathrm{w}}$ (root dry weight), $\mathrm{L}_{\mathrm{v}}$ (root length) and $\overline{\mathrm{A}}_{\mathrm{p}}$ (root area) measured in all soil profiles of two vines irrigated by microsprinklers in Petrolina (1996).

a

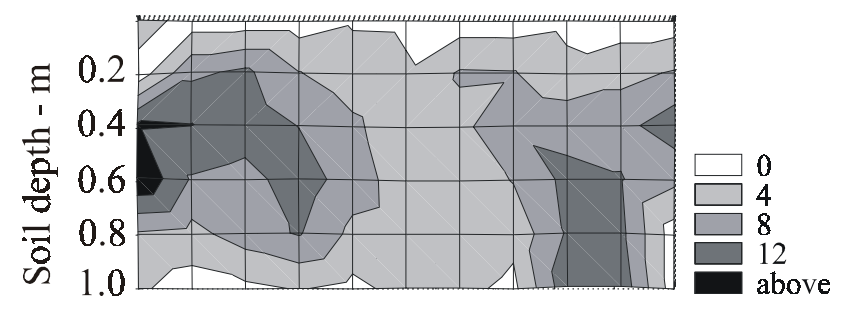

c

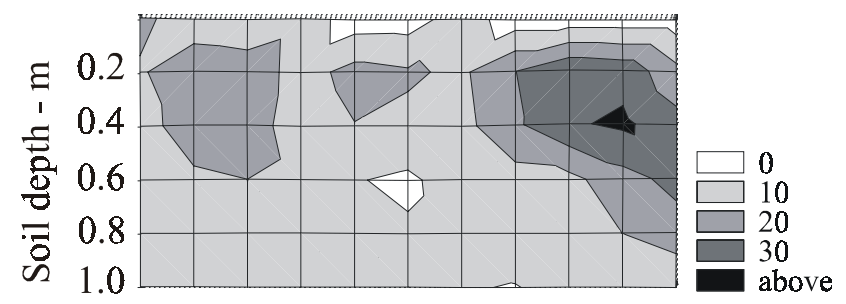

b

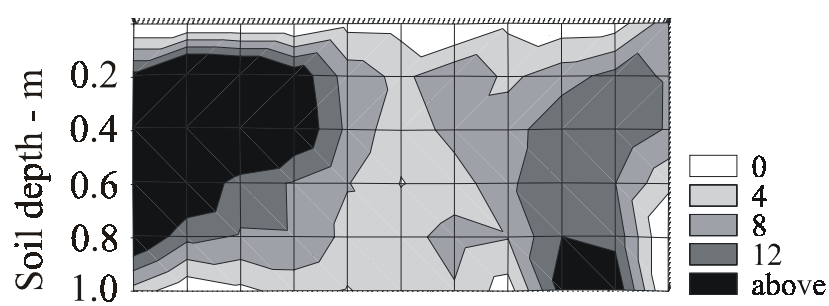

Figure $6-\overline{\mathrm{A}}_{\mathrm{p}}$ - root area $\left(10^{-4} \mathrm{~m}^{2}\right)$ distribution over 0.8-1 (a), 0.6-0.8 (b), 0.4-0.6 (c), and 0.2-0.4 m (d) soil profiles in Juazeiro. 
$0.6,0.8$, and $1 \mathrm{~m}$ from plant rows. These estimations are within the diameter intervals where most of $\mathrm{D}_{\mathrm{w}}$ and $\mathrm{L}$ were found in the Petrolina County and by other studies already mentioned.

In conclusion, the grapevine cv. Italia, grafted on the rootstock IAC-313 and grown under drip and microsprinkler irrigation, presented a root system that reached $1 \mathrm{~m}$ in the vertical and horizontal directions from the trunk, in a coarse textured soil. However, much of the root system was present in the soil volume covered by the $0.4 \mathrm{~m}$ depth and by the perpendicular distance of 0.6 $\mathrm{m}$ from plant row. In some portions of the soil, root amounts were higher as the distance from the trunk increased (vertical and horizontal directions) for plants under microsprinkler irrigation, while drip irrigated grapevines presented higher root presence near to the trunk. Roots with diameter less than $2 \mathrm{~mm}$ were at least $80 \%$ of the total root length.

Correlation among dry weight, root length density and root area were reasonable, but correlation among their fractional distributions over the soil profile were higher, which lead to similar conclusions on root distribution. Because of its good correlation with root length density, root area or root length estimated by the soil profile method combined with digital image analysis can be used to evaluate grapevine rootstocks.

\section{ACKNOWLEDGEMENT}

95-5).

To CNPq for finantial support (project $n^{\circ} 521376 /$

\section{REFERENCES}

ARAUJO, F.J. Table grape production in tropical America. In: INTERNATIONAL SYMPOSIUM ON TABLE GRAPE PRODUCTION, 1., Davis, 1994. Proceedings. Davis: J. M. Rantz, 1994. p.31-37.

ARAÚJO, F.; WIILIAMS, L.E.; GRIMES, D.W.; MATTHEWS, M.A. A comparative study of young "Thompson Seedless" grapevines under drip and furrow irrigation. I. Root and soil water distributions. Scientia Horticulturae, v.60, p.235-249, 1995.

ATKINSON, D. The distribution and effectiveness of the roots of tree crops. Horticultural Reviews, v.2, p.424-490, 1980.

BASSOI, L.H.; SILVA, J.A.M.; ALENCAR, C.M.; RAMOS, C.M.C; JORGE, L.A.C.; HOPMANS, J.W. Digital image analysis of root distribution towards improved irrigation water and soil management. In: ANNUAL ASAE/CSAE INTERNATIONAL MEETING, Toronto, 1999. Proceedings. St Joseph: ASAE, 1999. paper 992225.

BAUHUS, J,; MESSIER, C. Evaluation of fine root length and diameter measurements obtained using RHIZO image analysis. Agronomy Journal, v.91, p.142-147, 1999.

BOHM, W. Methods of studying root systems. New York: Springer-Verlag, 1979. 194p.

BRAVDO, B.; HEPNER, Y. Water management and effect on fruit quality in grapevines. In: AUSTRALIAN WINE INDUSTRY TECHNICAL CONFERENCE, 6., Adelaide, 1987. Proceedings. Adelaide: Australian Industrial Publishers, 1987. p.150-158.

CLOTHIER, B.E.; GREEN, S.R. Roots: The big movers of water and chemical in soil. Soil Science, v.162, p.534-543, 1997.
COMMINS, P.J.; MCBRATNEY, A.B.; KOPPI, A.J. Development of a technique for the measurement of root geometry in the soil using resinimpregnated blocks and image analysis. Journal of Soil Science, v.42, p.237-250, 1991.

CRESTANA, S.; GUIMARÃES, M.F.; JORGE, L.A.C.; RALISH, R.; TOZZI, C.L.; TORRE, A.;VAZ, C.M.P. Avaliação da distribuição de raízes no solo auxiliada por processamento de imagens digitais. Revista Brasileira de Ciência do Solo, v.18, p.365-371, 1994.

DOWDY, R.H.; SMUCKER, A.J.M.; DOLAN, M.S.; FERGUSON, J.C. Automated image analysis for separating plant roots from soil debris elutrated from soil cores. Plant and Soil, v.200, p.91-94, 1998.

EMPRESA BRASILEIRA DE PESQUISA AGROPECUÁRIA. Manual de métodos de análise de solo. 2.ed. Rio de Janeiro: EMBRAPA, CNPS, 1997. 212p.

FREEMAN, B.M. Effect of soil profile and management on grap evine development and grape quality. In: AUSTRALIAN WINE INDUSTRY TECHNICAL CONFERENCE, 7., Adelaide, 1990. Proceedings. Adelaide: The Australian Wine Research Institute, 1990. p.26-28.

GALE, M.R.; GRIGAL, D.K. Vertical root distributions of northern tree species in relation to successional status. Canadian Journal of Forest Research, v.17, p.829-834, 1987.

HOMAEE, M. Root water uptake under non-uniform transient salinity and water stress. Wageningen: Agricultural University Wageningen, 1999. (Thesis - Ph.D.).

KASPAR, T.C.; EWING, R.P. ROOTEDGE: Software for measuring root length from desktop scanner images. Agronomy Journal, v.89, p.932940, 1997.

KIMURA, K.; KIKUCHI, S.; YAMASAKI, S. Accurate root length measurement by image analysis. Plant and Soil, v.216, p.117-127, 1999.

KIRCHHOF, G.; BLACKWELL, J.; SMART, R.E. Growth of vineyard roots into segmentally ameliorated acidic subsoils. Plant and Soil, v.134, p.121-126, 1991.

KLEPPER, B. Roots: past, present and future. In: INTERNATIONAL POTASH INSTITUTE. Roots of plant nutrition. Champaign: POTAFOS, 1992. p.7-18.

KOZINKA, V. Uptake and transport of water. In: KOLEK, J.; KOZINKA, V. (Ed.) Physiology of the plant root system. Dordrecht: Kluwer Academic Publishers, 1991. p.129-203.

LYNCH, J. Root architecture and plant productivity. Plant Physiology, v.109, p.7-13, 1995.

MATTHEWS, M.A; ANDERSON, M.M. Fruit ripening in Vitis vinifera L.: Responses to seasonal water deficits. American Journal of Enology and Viticulture, v.39, p.313-320, 1988.

MORANO, L.; KLIEWER, W.M. Root distribution of three grapevine rootstocks grafted to Cabernet sauvignon grown on a very gravelly clay loam soil in Oakville, California. American Journal of Enology and Viticulture, v.45, p.345-348, 1994.

MORLAT, R.; JACQUET, A. The soil effects on the grapevine root system in several vineyards of the Loire valley (France). Vitis, v.32, p.35-42, 1993.

MURPHY, S.L.; SMUCKER, A.J.M. Evaluation of video image analysis and line-intercept methods for measuring root systems of alfafa and ryegrass. Agronomy Journal, v.87, p.865-868, 1995.

MYBURGH, P.A. Effect of ridging on the performance of young grapevines on a waterlogged soil. South African Journal of Enology and Viticulture, v.15, p.3-8, 1994.

NAGARAJAH, S. Effects of soil texture on the rooting patterns of Thompson Seedless vines on own roots and on Ramsey rootstock in irrigated. American Journal of Enology and Viticulture, v.38, p.54-59, 1987.

NAPPI, P.; JODICE, R.; LUZZATI, A.; CORINO, L. Grapevine root system and VA mycorrhizae in some soils of piedmont (Italy). Plant and Soil, v.85, p.205-210, 1985

PADGETT-JOHNSON, M. Vine water relations, gas exchange, growth and root distribution of several Vitis species under irrigated and non-irrigated conditions. Davis: University of California, Davis. 1999. (Thesis -Ph.D.).

PERRY, R.L.; LYDA, S.D.; BOWEN, H.H. Root distribution of four Vitis cultivars. Plant and Soil, v.71, p.63-74, 1983.

REICHARDT, K. Soil physico-chemical conditions and the development of roots. In: RUSSEL R.S.; IGUE, K.; METHA, Y.R. (Ed.) The soil/ root system in relation to Brazilian agriculture. Londrina: IAPAR, 1981. p.103-114.

Scientia Agricola, v.60, n.2, p.377-387, Abr./Jun. 2003 
RICHARDS, D. The grape root system. Horticultural Reviews, v.5, p.127168,1983

ROWE, R.N. The growth of grapevines: the role of roots. Wine Industry Journal, v.8, p.326-328, 1993.

RUARK, G.A.; BOCKHEIM, J.G. Digital image analysis applied to soil profiles for estimating tree root biomass. Soil Science, v.146, p.119123, 1988.

STEVENS, R.M.; DOUGLAS, T. Distribution of grapevine roots and salt under drip and full-ground cover microjet irrigation systems. Irrigation Science, v.15, p.147-152, 1994.

TAGLIAVINI, M.; VETO, L.J.; LOONEY, N.E. Measuring root surface area and mean root diameter of peach seedlings by digital image analysis. HortScience, v.28, p.1129-1130, 1993

TEIXEIRA, A.H.C; AZEVEDO, P.V.; SILVA, B.B.;SOARES, J.M. Consumo hídrico e coeficiente de cultura da videira na região de Petrolina,PE. Revista Brasileira de Engenharia Agrícola e Ambiental, v.3, p.413-416, 1999
TENNANT, D. A test of modified line intersect method of estimating root length. Journal of Applied Ecology, v.63, p.995-1001, 1975.

VAN ZYL, J.L. Response of grapevine to soil water regimes and irrigation systems. In: VAN ZYL, J.L. (Ed.) The grapevine root and its environment. Pretoria: Department of Agriculture and Water Supply, 1988. p.30-43.

VAN ZYL, J.J.; VAN HUYSSTEEN, L. Soil and water management for optimum grape yield and quality under conditions of limited or no irrigation. In: AUSTRALIAN WINE INDUSTRY TECHNICAL CONFERENCE, 5., Adelaide, 1984. Proceedings. Adelaide: The Australian Wine Research Institute, 1984. p.25-67.

WILLIAMS, L.E.; SMITH, R.J. The effect of rootstock on the partitioning of dry weight, nitrogen and potassium, and root distribution of Cabernet Sauvignon grapevines. American Journal of Enology and Viticulture, v.42, p.118-122, 1991.

Received March 20, 2002 